\author{
Jelena Birovljev \\ University of Novi Sad \\ Faculty of Economics Subotica \\ Department of Agricultural \\ Economics and Agribusiness \\ Biljana Ćetković \\ University of Novi Sad \\ Faculty of Economics Subotica \\ Department of Agricultural \\ Economics and Agribusiness \\ Goran Vukmirović \\ University of Novi Sad \\ Faculty of Economics Subotica \\ Department of Trade, Marketing and

\section{PROSPECTS OF IMPROVING THE COMPETITIVENESS OF SERBIAN AGRICULTURE IN (RE)INDUSTRIALIZATION PROCESS} \\ Perspektive unapređenja konkurentnosti \\ poljoprivrede Srbije u procesu (re)industrijalizacije \\ Logistics
}

\begin{abstract}
Competitiveness in the international business environment is a key instrument of success and evaluation of created value of all participants in the value chain. It can be assessed using a variety of indicators, taking into account many factors affecting its complex structure. Hence, it is a framework affirming the competitive advantages/disadvantages on the macro and micro-level as well as on the level of companies and their product offer. Competitiveness can be analyzed at the levels of national economy, industrial sectors, as well as individual products level. The most common approach to the comparison of achieved competitiveness level relates to product costs and/or market price compared to quality (value) aspects of the product/service.

Prices and the quality of inputs feature as the starting points for competitiveness of the national economy. Efficiency of operations recognizes the impact of all inputs, especially those whose relative share in the total production cost is high. In contrast to the highly automated production processes, agriculture remains a labour-intensive activity, despite the increase in the level of automation. It is an exception compared to other industries due to the high impact of the effects of climate and other natural factors productivity. At the same time, agriculture is a very important economic and social field of activity, and different concepts of macroeconomic measures are developed in different national economies to stimulate the balanced regional development of agricultural production. Macroeconomic factors that determine overall business environment for the development and competitiveness of agriculture have a very high level of impact on the competitiveness of agricultural products in the Republic of Serbia.
\end{abstract}

Key words: competitiveness, price comparison, macroeconomic measures

\section{Sažetak}

Konkurentnost u međunarodnom poslovnom okruženju predstavlja ključni instrument uspeha, odnosno evaluacije stvorene vrednosti svih učesnika u lancu vrednosti. Ona se može vrednovati pomoću različitih pokazatelja, uz uvažavanje velikog broja faktora od uticaja na njenu složenu strukturu. Otuda ona predstavlja okvir kojim se potvrđuju konkurentske prednosti/nedostaci, kako na makro nivou, tako i u odnosu na mikro nivo odnosno same privredne subjekte i njihovu ponudu. Konkurentnost se može posmatrati na nivou čitavih nacionalnih privreda, industrijskih grana i sektora, kao i na nivou pojedinačnih proizvoda. Najčešći pristup komparaciji dostignutog nivoa konkurentnosti dovodi u vezi iskazanu cenu koštanja i/li prodajnu cenu u odnosu na kvalitativne (vrednosne) aspekte proizvoda/usluge.

Polazna tačka u ostvarivanju konkurentnosti celokupne nacionalne ekonomije su cene i kvalitet inputa. Efikasnost poslovanja uvažava uticaj svih inputa, a posebno onih čije je relativno učešće u ukupnoj ceni koštanja visoko. Za razliku od visoko automatizovanih proizvodnih procesa, poljoprivreda i pored porasta stepena automatizacije i dalje predstavlja radno intenzivnu delatnost. To je izdvaja u odnosu na druge privredne grane zbog visokog uticaja produktivnosti, kao i uticaja klimatskih i drugih prirodnih faktora. Istouremeno, poljoprivreda predstavlja i veoma značajan ekonomsko-socijalni sektor, pa su u različitim nacionalnim ekonomijama prisutni razliciti koncepti makroekonomskih mera kojima se stimuliše ravnomeran regionalni razvoj poljoprivredne proizvodnje. Veoma visok nivo uticaja na konkurentnost poljoprivrednih proizvoda u Republici Srbiji imaju makroekonomski faktori koji opredeljuju opšti poslovni ambijent za razvoj poljoprivrede i njenu konkurentnost u celini.

Ključne reči: konkurentnost, komparacija cena, makroekonomske mere 


\section{Introduction}

The relative share of agriculture in the total GDP of national economies at the EU level is currently showing a declining trend. As regards Central and Eastern Europe, agriculture employs over 10 million people, and its average share in the GDP amounts to approximately 7\%. As well as Bulgaria, Romania, Hungary, Poland, the Czech Republic, and Slovakia, the competitiveness of agriculture in the Balkans countries including Serbia is highly subject to changes influenced by the liberalisation of national markets brought about by EU integrations. These trends point to the need for faster responses that are required at both macro and micro levels, in order to enable the improvement of general competitiveness of Serbian agriculture and processing industry.

The concept of competitiveness of a particular industry should not be identified with a company's competitive advantage. The potential of achieving the competitiveness of Serbian agriculture can be affected by various macroeconomic factors. They can make a direct or indirect (de)stimulating impact on the efficiency improvement of all business processes in creating the value chain of agricultural products. It must be pointed out that the sales prices of agricultural products are formed based on the prices of inputs invested in agricultural production, which can be achieved on the national markets of labour, capital, seed cultures, chemical fertilisers, petroleum products, and also logistic services such as transport and storage. These factors play an external role in creating the value chain of agricultural products, and are beyond the control of the key carriers of agricultural activities. Seasonal and annual oscillations in the prices of these factors may make a positive or negative impact on the final cost price, with the simultaneously present rank of statistical significance of their effect.

\section{Competitiveness: Theoretical approaches and definitions}

The concept of competitiveness has been developing in the economic theory and practice in parallel with the rapid internationalisation processes of national markets in the second half of the twentieth century. Despite numerous attempts, economic theory has not offered a universal definition of competitiveness. Different approaches to defining it result from a very broad scope, which should offer an appropriate framework for the conceptual determination of competitiveness at the levels of products, product groups, companies, industries and/or national economies in various temporal and spatial conditions [1]. According to some authors like Porter, the concept of productivity is not applicable on the level of national economy; only national productivity can be used here.

As regards the limitations of the application of competitiveness at the national economy level, it is necessary to point to different definitions focussing on the ability of particular countries to increase the share of their own products on the domestic and international market. A particular country, region and/or sector can have the competitive advantage of the products that they can produce at lower costs in comparison to competitors, maintaining the quantity and quality levels. In other words, competitiveness as a framework must take into consideration the characteristics of the structure of the market segment and the buyers' needs. The stress in the orientation to competitive struggle must be placed on the choice of an appropriate competitive strategy in order to create an optimum value change. The value chain shows the total generated value of a product or service, resulting from synchronised physical and technological activities of transforming inputs into a new product with a value for the final customer. Porter lists five generic categories of primary activities essential for achieving high competitiveness in an industry: inbound logistics, operations, outbound logistics, marketing and sales, and service (see Figure 1).

Figure 1: Generic value chain

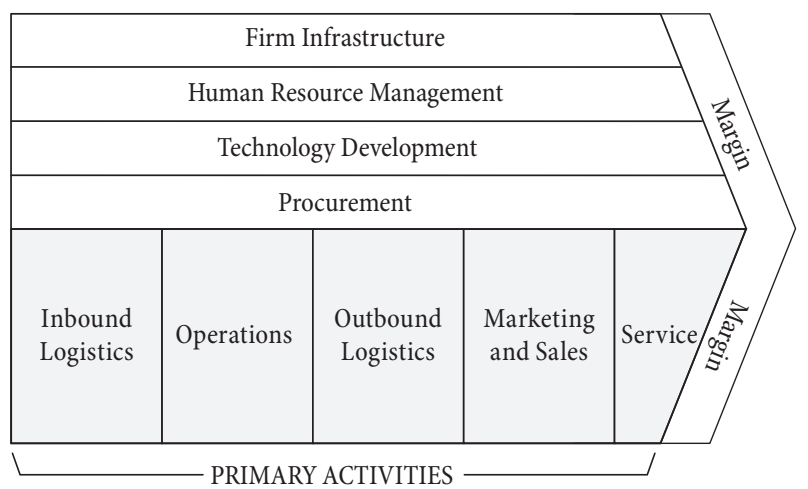


The primary activities of the generic value chain point to possible points for creating competitive advantages or disadvantages, expressed as relative costs of production in relation to other regions and countries. Some theoreticians, such as Chenery, point out that the state can generate international competitiveness of its agricultural products if the price of all the factors influencing agricultural production is lower than the export prices, i.e. average price on international produce exchanges. Economic theory has developed several models for measuring competitiveness, such as the Global Competitiveness Index (GCI) and the Domestic Resource Cost (DRC) ratio. It is interesting to note that, according to the Global Competitiveness Report 2009-10, Serbia takes up the $93^{\text {rd }}$ place of 133 evaluated countries, i.e. national economies. The GCI index is the synthesis of assessments of their national economies by 12 observed competitiveness factors, including expanded market dominance (oligopoly), market efficiency, effectives of anti-monopoly policies and the intensity of local competition. These very factors appear as the key weaknesses of the Serbian national market compared to other countries [12, p. 123].

The Domestic Cost is a model for assessing the international product prices. It enables comparing the opportunity costs of national production with the value added created based on this. It is the ratio between the sum of costs of used domestic resources such as soil, labour and capital (inputs not traded at the international level) and the value added (value of outputs minus value of inputs, expressed through unit prices) - formula $1[8$, p. 3].

$$
D R C_{i}=\frac{P_{i}^{r}-\sum_{j=k+1}^{n} a_{i j} V_{j}}{P_{i}^{r}-\sum_{j=1}^{k} a_{i j} P_{j}^{r}}
$$

If the $\mathrm{DRC}$ ratio value is below 1 , national production is efficient and competitive on the international market. In that case, the opportunity costs of using domestic resources are lower than net selling prices on the international market, or their sale on the national market results in the reduction of the import of equivalent products from abroad. DRC ratio value above 1 indicates a lower competitiveness level of domestic products compared to international competitors. The DRC approach enables comparing comparative advantages between economic values not only at the national, but also in the international level, but it is characterised by significant limitations in its application as well.

Numerous researchers (Ratinger, Gordon, Banse, Deaconescu, Michalek, Bozik, Kuhar etc.) have conducted their studies based on the DRC ratio. The studies encompassed assessment of competitiveness of crops and produce (between 5 and 15 products such as wheat, maize, sunflower seed, sugar beet, potatoes milk, eggs, pork, beef and poultry) in the countries of Central and Eastern Europe. According to the results of these studies, highly competitive products in countries such as Bulgaria, Romania and Hungary are predominantly wheat, maize and sunflower seed, whereas milk, beef and pork from these countries were highly uncompetitive when compared to the leading countries of the European Union [7, p. 6-8]. Considering the similarities that agricultural production in Serbia shares with the neighbouring countries, it can be concluded that price competitiveness of domestic produce is relatively low compared to the EU, except for wheat, maize and sunflower, which is also accompanied by a growing trend in the prices of these agricultural products at the global level.

When applying the DRC model, researchers are often faced with data unavailability or inadequacy for expressing the social costs, which need to be derived from accounting data $[4$, p. 26].

\section{The impact of macroeconomic factors on competitiveness levels}

Research into competitiveness is a complex area, where ex post analysis of competitive advantages and competitiveness can produce comparatively low amounts of data on the causes of (un)competitiveness of a country and its agricultural sector. One of the key groups of factors of influence on the total competitiveness of a country's agriculture is adapting to the volatile conditions of the international market, i.e. creating the measures of macroeconomic and agrarian policies with direct and indirect effect on the costs of agricultural production. A significant impact on the price competitiveness of Serbian produce is exerted by the following factors: foreign exchange rates, interest 
rates, taxation policies, measures of subsidising agricultural production, traffic infrastructure and logistics.

\section{Foreign exchange rates}

Serbia uses the policy of floating exchange rates, with daily and seasonal fluctuations, resulting in relatively difficulty of cost calculations for invested inputs, expressed, for instance, in euros, especially in agriculture and other industries with longer production cycles. As a rule, in the period from 2007 till 2013, the exchange rate was 3-5\% higher in the spring sowing period compared to the period of harvest and sale of primary produce. This fact resulted in the fact that, through the price of imported inputs (such as chemical fertilisers, seed, petroleum products, pesticides, etc.), the cost price of primary produce expressed in euros included a negative difference causing a reduced international competitiveness of domestic products.

The declining trend of the exchange rate (from 75RSD/1EUR in September 2008 to 117RSD/1EUR in September 2012) also makes a positive impact on the price competitiveness of Serbian primary agricultural products at the international level. Growth in exchange rate results in declining levels of prices of wheat, maize and sunflower seed exported from Serbia, thus causing "artificial" rise in their competitiveness, together with the growing trends in produce exchange prices of these commodities on the global level. Still, in the prevailing oligopoly conditions of purchase of cereals and oil crops, the greatest extra profit effect of such a rise of Serbian produce is achieved by a small number of leading companies in the agribusiness sector.

\section{Interest rates}

The price of capital employed is expressed as interest rate on assets employed for short-term and long-term borrowing in order to finance agricultural production. Despite being mostly privatised, the Serbian banking market failed to achieve a high level of independence in comparison with the terms and conditions of foreign credit lines, (notably Greek, Italian and Austrian). A relatively low credit rating of Serbia, high compulsory reserves of commercial banks at the Central Bank of Serbia, political risk and banks' shortterm orientation to achieving positive business results have affected the limited level and relative unavailability of credit lines for long-term crediting of agricultural production. Another limiting factor in obtaining long-term loans for agriculture after 2008 was the impossibility of mortgaging agricultural land, which definitely diminished the credit potential of farms and agricultural companies. In the previous period, the Government of Serbia had conducted programmes of subsidising interest rates for dedicated loans for agriculture, but the effects were comparatively low due to various limitations in the application procedure, and insufficient funds in relation to manifested requirements of agricultural producers. In comparison with the leading EU countries, the average difference in interest rates on loans in Serbia ranges between $5 \%$ and $10 \%$, resulting in lower price-based competitiveness of domestic agricultural commodities.

\section{Taxation policies}

The level of taxes can affect the short-term positions of agricultural products, and the level of long-term investment in agricultural production. The short-term effect of taxation policies is present when tax and/or excise rates are changed. The increase in the overall VAT rate from $18 \%$ to $20 \%$ in Serbia [19] resulted in a growth in prices of all products, including various inputs for primary agricultural production. If we add to this the raised excises on crude oil and petrol products, and the prices of these commodities on the global level, the period from 2007 till 2013 saw a nominal growth in oil prices on the Serbian market of over $100 \%$. The rising oil prices directly affect the cost price of primary produce, whereas the indirect impact can be valuated through the growth in the price of logistic prices, notably road transport.

It is important to point out that Serbia has adopted various incentive measures through tax reliefs for direct investment in all agricultural sectors. Investors investing over 7,000,000 euros in production cycle or employ a minimum of 100 new employees are exempt from corporate profit tax for a period of 10 years [17]. In view of the fact that the major part of investment in primary agricultural production comes from domestic sources, i.e. accumulation of the agricultural producers themselves, a more significant investment cycle in the Serbian agriculture 
failed to happen. The majority of agricultural land is owned by small farmers (less then 5 hectares), which is similar to Italy (69\%), Greece (69\%), and Spain (50\%), so that taxation policy instruments should be developed at the macroeconomic level, which would, in combination with agrarian policies, act as an incentive not only for large companies, but primarily for small and medium farmers. Taxation policy measures, such as reducing and/ or exemption from VAT for investment in technological equipment, storage facilities or long-term plantations could result in attracting available funds from the deposits of companies and banks' retail clients.

\section{Subsidising agricultural production}

The programmes of subsidising agricultural production are oriented to financial forms of assisting private persons, entrepreneurs and legal persons in terms of credit support to the development of cattle farming, crop and vegetable farming, fruit plantations, viticulture, capital investment in agricultural machinery, equipment and/or facilities [10]. Unlike the implemented subsidy programmes of the Serbian Government in the period 2000-2012, which were subject to frequent changes in the terms and conditions of utilisation, available amounts and the system of calculation and disbursements with frequent delays [18], the European Union leads a policy of continuous subsidies in agriculture. The EU applies flat rate payment, i.e. subsidising per hectare of agricultural land, disbursed directly to farmers. The average subsidy rate in the EU15 countries is three to four times as high as in Serbia, ranging between 300 and 400 euros per hectare. Reduction of available budget funds earmarked for subsidies will make a direct negative impact on the price competitiveness of domestic agricultural products on the international market.

\section{Traffic infrastructure and logistics}

The development of traffic infrastructure is a factor of indirect effect on the competitiveness of all the industries of a national economy. Comparative research into the characteristics of efficiency of national economies and their macro-logistic systems points to a high level of positive correlation. In other words, if a country or a region has a prevailingly low development level of traffic infrastructure, this will be transferred to a decreased efficiency of other industries, i.e. the overall national economy my means of logistic services. The competitiveness of the Serbian logistic sector can be valuated through the Logistic Performance Index (LPI). According to the LPI value, Serbia took up the $83^{\text {rd }}$ place at the global level in 2010 , and its position is worse compared to the surrounding countries - Hungary, Bulgaria, Romania and Slovenia [15, p. 7]. The average share of logistic costs exceeds $10 \%$ of the overall costs of agricultural production, so that the relative inefficiency of this sector is reflects negatively on the price competitiveness of Serbian cereals and other produce.

\section{A systemic approach to improving technology- and knowledge-based agricultural production}

The characteristics of agricultural production are highly different when viewing the national economies of the leading G20 countries, and other regions globally. As a rule, the specifics of agricultural production show that, from the aspect of competitiveness of agricultural products, the most competitive national economies also have the highest level of technological, infrastructural and distribution capacities. When comparing highly competitive agricultures of the most developed country with the less competitive agricultures, one can notice a difference in the approach to managing available resources, such as human resources, capital, physical resources and infrastructure. In most cases, agricultural production in less developed national economies bases its comparative advantages on possible advantages in physical and/or human resources, based on low unit cost of these inputs.

The effect of these advantages has a relatively low of impact on the overall competitiveness, especially in the areas of agriculture with higher potential of the share of capital, logistic and other infrastructure, that is, participation of and knowledge in the development of intensive agricultural production. The competitiveness of the Serbian agriculture can be assessed in relation to the analysis of comparable competitiveness elements of CEFTA countries, or EU-15 countries, or EU-27 countries. The agriculture of Serbia records positive results in total export and import, so that the period 2000-2012 shows 
a growing trend with an increased net export level. If, however, we view the structure of foreign trade, it is evident that the total export is dominated by cereals, sugar, fresh and frozen fruit and vegetables (80\%), whereas meat and meat products account for only $3-4 \%$ [11, p. 85$]$. It is obvious that the competitiveness of domestic agricultural products is based on lower pricing elements of human and physical resources, and only in the production and trade of commodities with low innovation rates and low participation of technology and knowledge. In all other segments, farmers are unable to achieve competitive advantages without developing a systemic approach based on cooperation, introduction of innovation and new, knowledge-based technologies, and clusterisation aimed at increasing the total efficiency of production (see Figure 2). Serbian farmers encounter various problems in terms of the implementation of new knowledge, limited amount of available capital (especially for long-term investment), inappropriate or inefficient internal and external logistics characterised by prevalence of road transport, limited transshipment facilities, unequal structure of storage facilities across regions, etc.). Bearing in mind the predominant size of farms, education levels, and potential for investment in modernising agricultural production, Serbian farmers must turn to pooling their capacities with other economic entities in cluster production.

Predispositions for cluster development in Serbia do not include only the farmers' willingness or need to participate; what is necessary is creating an appropriate environment at the agro-economic policy level, by means of creating a stable macroeconomic environment; establishing research and development institutions, professional consulting and knowledge bases; developing traffic and market and infrastructure; developing systems and institutions for quality standardisation; investing in education, technology and sophisticated methods, and finally, providing loans, funds, subsidies etc. in order to raise investment levels and increase the technological level of agricultural production [9, p. 301].

In comparison with individual farmers, farms and agricultural companies, the cluster-based agricultural production bases its advantages on lower prices of inputs

Figure 2: A model of production with the market-focused technology development system

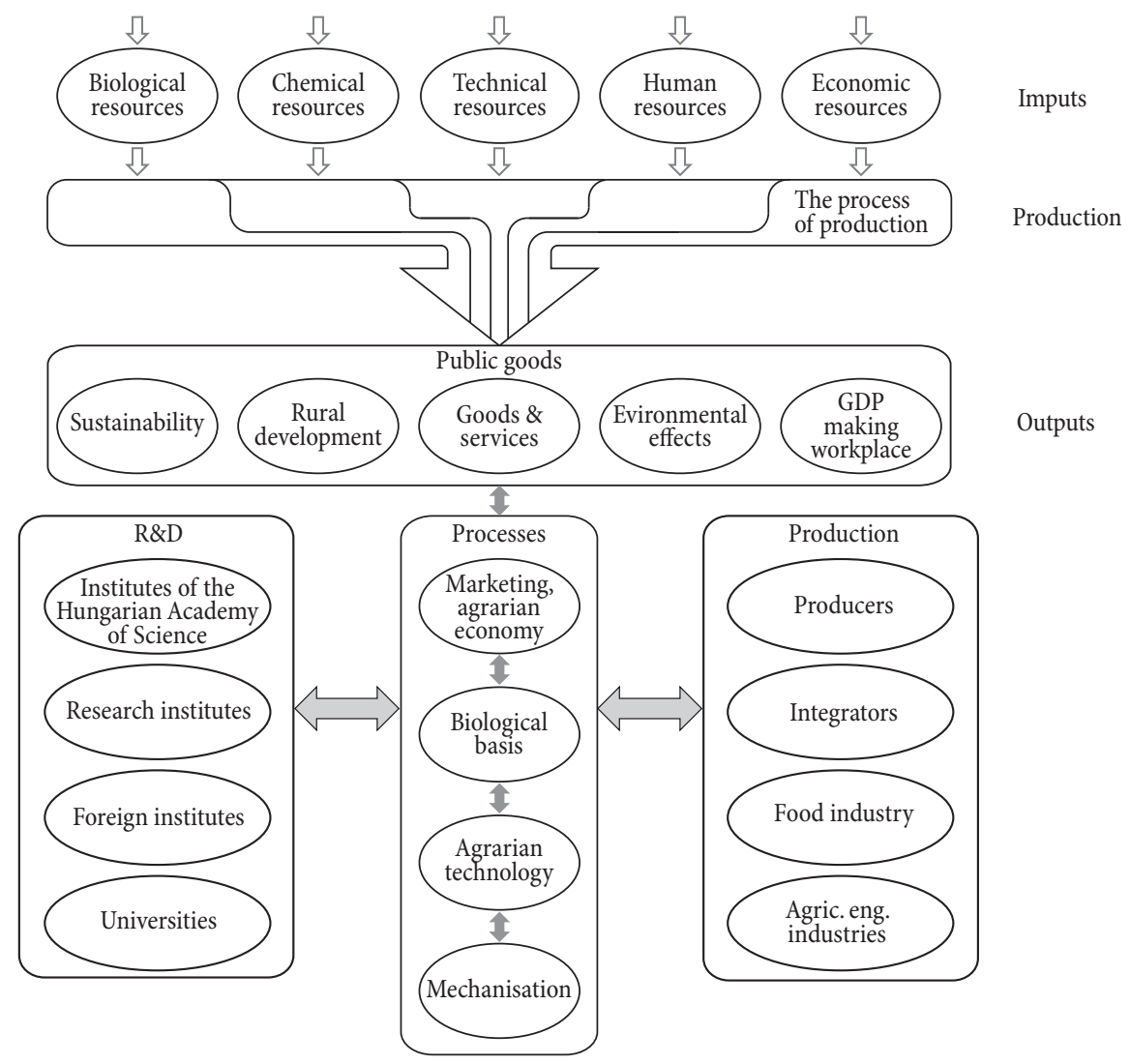


(especially of imported component), higher levels of knowledge based on cooperation with universities and institutions, and higher efficiency in the automation of production processes and implementation of up-to-date strategies in logistics and the distribution of agricultural products. Compared to small individual farms sized up to 50 hectares, the average level of cost-based competitive advantage of cluster-based production in the $\mathrm{EU}$ is $30-40 \%$ higher in cereals, and products with higher finalisation levels, cluster-based production records significantly higher pricing advantages [8].

The ownership structure of agricultural land in Serbia, with a high share of small farms (77.4\%) indicates limited potentials for a higher level of investment in knowledge, agricultural machinery, storage and other logistic capacities. Therefore, lack of a broader framework for cluster production has resulted in the lack of investment in agriculture, especially when considering foreign direct investment. Average non-resident investment in Serbian agriculture between 2004 and 2010 ranged accounted for 0.2 and $1.6 \%$ of total investment [5], which is a very low share, indicating limited effects in terms of transfer of knowledge and new technologies.

\section{Measures for improving the competitiveness of Serbian agriculture}

Raising competitiveness levels implies developing, adopting and implementing the priorities of the Serbian agriculture aimed at increasing the productivity and cost-effectiveness of processes, with the additional objective of achieving either lower unit price of output and/or enhanced product quality. In other words, it is essential to maintain and exploit the competitive advantage of domestic agricultural production by using the positive differences in natural potentials (such as climate, soil and water resources), and enhancing the qualitative characteristics of agricultural products (production of higher-quality varieties, certified production, organic production, creating trade marks and other distributive advantages through the protection of geographic origin, brands, packaging design etc.). In other words, it is necessary to use the factors influencing the improvement in competitiveness through three groups of factors - the factors of raising the level of technical equipment and productivity at the micro level (the farm or enterprise level); macro factor such as protecting property rights, intellectual property, legal protection level, deregulation and agro-economic measures; and factors based on knowledge and technology transfer through including educational and scientific institutions in joint agricultural production and processing at the cluster level.

The system of measures for enhancing competitiveness represents a complex and diversified concept, as numerous factors of influence and applied measures have different degrees of identity and direction of action on raising the cost- and quality based advantages of the agricultural sector. Based on their effects, the measures for enhancing the competitiveness of Serbian agriculture can be diversified into several groups:

- Increasing the share of large producers with a direct effect on the increase in productivity through economies of scale;

- Regulating the produce market through reducing monopoly and oligopoly, and establishing price stability on the domestic and international market;

- Strengthening the role of state institutions through increasing agrarian budget, higher share of subsidies and support to cluster production;

- Constructing an irrigation system and lower dependence on climatic factors;

- Educating rural population and developing incentive measures for investing in rural areas through tax reliefs, favourable crediting terms and conditions for agricultural production in rural areas;

- Increasing the average size of farms and reducing the number of small individual farms outside cooperatives and clusters;

- Faster implementation of standards in food production with the emphasis on supporting organic agricultural production;

- Encouraging the development of small agribusiness and entrepreneurships through support in obtaining technical equipment, knowledge transfer and consulting, and other forms of financial and expert assistance through agricultural funds and programmes. 
Orientation to the creation of cost-based advantages in the Serbian agricultural production has a relatively limited effect, as the advantages in terms of economies of scale can be achieved only in relation to the neighbouring countries of the CEFTA region due to high dependence on logistic costs. This is exactly why the Serbian agriculture should (re) orient itself to raising qualitative characteristics as a basis for improving competitiveness. Quality standards (ISO 9000, ISO 22000, HACCP, GMP and GHP) are insufficiently present among farmers and processing entities, especially in the entrepreneurship sector in agribusiness and processing industry. The reasons for this can partly be sought in inadequate knowledge of legislation, but also in the lack of systemic support through cluster association, without which individual farmers do not possess sufficient knowledge, capital and technological equipment to meet and apply the above mentioned standards in their own production.

One of the possible avenues of developing Serbian agriculture is the segment of organic production, which can contribute to socio-economic and environmentally sustainable development of agriculture and economy in underdeveloped national economies [3, p. 9]. Serbia possesses a significant natural potential, favourable agrarian landscape, climate and water resources as vital prerequisites for developing organic agriculture. The average farm size of 3.5 ha and their fragmentation enable the involvement of a large number of producers in organic agriculture and mitigating economic and social tensions burdening this industry over the past years $[2$, p. 6].

\section{Conclusion}

Competitiveness of a product, economic activity, industry and national economy in general is a highly complex area of strategic management. The focus of synchronising different activities with the objective of achieving higher competitiveness on the international market is located within all the macroeconomic measures and microeconomic elements aimed at improving economic effectiveness and efficiency. The starting point for higher competitiveness is a comprehensive analysis of the existing resources aimed at agricultural production, and their comparison with comparable parameters on other national markets. Some of factors influencing the competitiveness level may have negative effects, whereas others make a positive impact on the competitiveness index. At the same time, it is necessary to point out that certain factors have predominantly shortterm and/or direct effects, whereas in most cases much better effects can be achieved with long-term agro-economic policy measures, with indirect impact on the productivity and cost-effectiveness of agricultural production.

The agriculture of the Republic of Serbia shows a somewhat higher degree of competitiveness compared to the overall competitiveness of the national economy. The structure of competitiveness of Serbian agriculture shows price-based competitive advantages of cereals and cerealbased products. It is the segment of fruit and vegetable production, fresh meat and processed meat sector that one can identify numerous "reserves" for enhancing efficiency and achieving price- and quality based competitive advantage of agricultural products. Enhancing the competitiveness can be achieved by combining macroeconomic and agroeconomic measures with the advantages of cluster-based association of entities. Clusters in the Serbian agriculture can contribute to a higher level of innovation, increased productivity and cost-effectiveness of agricultural production, which, in combination with the formation of new companies and adopting new technologies, can result in increased competitiveness at all levels - from basic farming to higher competitiveness of the overall agricultural sector and processing industry of Serbia.

\section{References}

1. Banse, M., Gorton, M., Hartell, J. et al. (1999, August). The evolution of competitiveness in Hungarian agriculture: from transition to accession. Paper presented at IXth European congress of Agricultural Economists, Warsaw, Poland.

2. Birovljev, J., \& Štavljanin, B. (2011). Development of organic food production in European countries with comparable resources. Strategic Management, 16(3), 23-33.

3. Birovljev, J., \& Štavljanin, B. (2012, December). The role of sustainable development and organic farming in preserving agriculture and rural values. Paper presented at International scientific conference Sustainable agriculture and rural development in terms of the Republic of Serbia strategic goals realization within the Danube region - preservation of rural values, Book of abstracts (p. 20), Tara. ISBN 978-866269-017-3. Belgrade: Institut za ekonomiku poljoprivrede.

4. Dunmore, J. C. (1986). Competitiveness and comparative advantage of U.S. agriculture. Economic Research Service, USDA. 
5. eKapia [business portal]. Retrieved from http://www.ekapija. com/website/sr/

6. European Commission. (1993). Economie Européenne. Rapport économique annuel pour 1993. Brussels: EC.

7. Fenyvesi, L., \& Erdeine Kesmarki-Gally, S. (2012). Boosting the competitiveness of agricultural production in Hungary through an innovation system. Studies in Agricultural Economics, 114(2012), 106-110. Retrieved from http://dx.doi. org/10.7896/j.1215

8. Gordon, M., \& Davidova, S. (2001, April). The international competitiveness of CEEC agriculture. Paper presented at British Association of Slavonic and East European Studies (BASESS) Conference, Cambridge.

9. Jefferson Institute. (2003). Konkurentnost privrede Srbije. Belgrade: Jefferson Institute.

10. Ministry of Agriculture, Forestry and Water Management. Bylaws. Retrieved from http://www.mpt.gov.rs/documents/ list/126/uredbe-poljoprivreda

11. Paraušić, V., \& Cvijanović, D. (2006). Značaj i uloga klastera u identifikaciji izvora konkurentnosti agrarnog sektora Srbije. Industrija, 34(1-2), 81-90.

12. Paraušić, V., Mihailović, B., \& Hamović V. (2010). Imperfect competition in the primary agricultural commodity market in Serbia. Economic Annals, 55(184), 113-150.
13. Porter, M. (1990). The competitive advantage of nations. New York: Free Press

14. Porter, M. (2007). Konkurentska prednost - ostvarivanje i očuvanje vrhunskih poslovnih rezultata. Novi Sad: ASEE.

15. Roca, B., \& Milićević, N. (2011, October). Neadekvatna primena koncepta o ekonomskoj efikasnosti i privredno-sektorski logistički system. Paper presented at Novi metodi menadžmenta i marketinga u podizanju konkurentnosti srpske privrede, NDES, Ekonomski fakultet Belgrade, Faculty of Economics in Subotica, Palić.

16. SEEDEV. (2012, December). Analiza trendova u proizvodnji i trgovini poljoprivrednih proizvoda iz Vojvodine u odnosu na proizvodnju i trgovinu u Srbiji, regionu, EU i svetu. AP Vojvodina: SEEDEV. Retrieved from http://195.178.40.73/poljoprivreda/ sites/default/files/Analiza_konkurentnosti_Seedev.pdf

17. SIEPA. (2013). Finansijska podrška za investitore. Retrieved from http://siepa.gov.rs/sr/index/finansiranje/finansijskapodrska-za-investitore

18. STIPS [Sistem tržišnih informacija poljoprivrede Srbije]. Retrieved from http://www.stips.minpolj.gov.rs/sadrzajv/isplatasubvencija-u-agraru-po\%C4\%8Dinje-slede\%C4\%87e-nedelje

19. Zakon o porezu na dodatu vrednost. The Official Gazette of the Republic of Serbia, Issues 84/2004, 86/2004 - amended in $61 / 2005,61 / 2007$ and 93/2012.
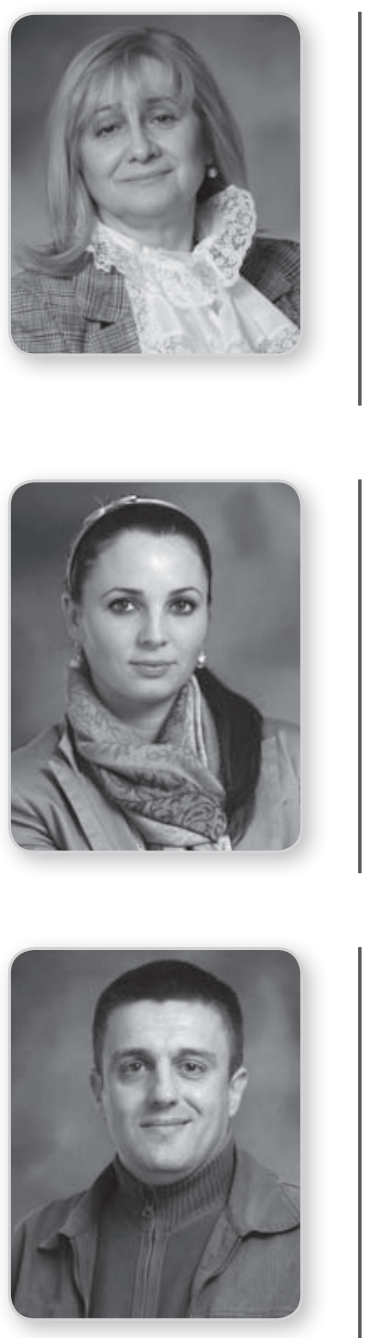

\section{Jelena Birovljev}

is a full professor at the Faculty of Economics in Subotica, University of Novi Sad. Her scientific research areas are management in agribusiness, agribusiness strategy and management of organic food production. She is a president of the Association of Economists in Subotica and a member of the Presidency of the Association of Economists of Vojvodina, as well as the Serbian Association of Economists. She is also a Vice Dean for Doctoral Studies at the Faculty of Economics in Subotica. She has published over 70 scientific papers, participated in more than 20 international conferences and has written 9 books. She lives and works in Subotica.

\section{Biljana Ćetković}

is a teaching assistant at Faculty of Economics Subotica, University of Novi Sad. Currently, she is a doctoral student at the Faculty of Economics Subotica in the field of agroeconomics. She participated in several national and international scientific conferences and published several scientific papers in national and international journals. She lives and works in Subotica.

\section{Goran Vukmirović}

is assistant professor at the Faculty of Economics in Subotica, University of Novi Sad. His scientific research areas are strategic positioning, competitive advantages, retail marketing, CRM. He has published over 20 scientific papers and taken part in national and international conferences. He lives and works in Subotica. 